\title{
PHYSICAL CHARACTERISTICS OF STUDENTS' RESIDENTIAL ENVIRONMENT IN RELATION TO DIETARY HABITS IN UNIVERSITY OF ILORIN, NIGERIA
}

\author{
${ }^{*}$ Adelabu, J.K., 2 Amole, D., and ${ }^{3}$ Ajayi, A. O., \\ 1Department of Architecture, University of llorin, Nigeria \\ 2Department of Architecture, Obafemi Awolowo University, lle-lfe, Osun State. \\ ${ }^{3}$ Department of Urban and Regional Planning, Osun State University, Osogbo. \\ ${ }^{*}$ Corresponding Author email: asemadahun.jk@unilorin.edu.ng; (+2347031297917)
}

\begin{abstract}
The design of students' residential environment has implication on their dietary habits. This study, which was conducted through a cross-sectional survey of students' resident oncampus, describes the physical characteristics of students' residential environment in relation to dietary habits in University of llorin, Nigeria. A multi-stage sampling technique was adopted and twelve (12) residence halls were purposively selected out of the twenty (20) residence halls on campus based on three criteria, namely: ownership, gender and design type. The systematic selection of $12 \%$ of students in each of the twelve (12) residence halls gave a total of 430 students that were used in the study. The data for the study were collected through the use of self-administered questionnaire and personal observation. Statistical analysis was done using the Statistical Package for Social Scientists (SPSS) software. The analytical tools used for the study were mainly descriptive statistics such as frequency tables and percentages. The result of the data analysis revealed that most $(67 \%)$ of the residence halls had kitchen en suite design and most (92\%) had butteries and restaurants within them to enhance the cooking and eating habits of students. The result also revealed that most of the food outlets $(72 \%)$ in the residential environment were mainly butteries and snack shops while few were restaurants $(18 \%)$. The study recommends that developers and stakeholders in student housing should pay more attention to the provision of facilities such as kitchens and restaurants that would enhance the cooking and eating of students within the residential environment.
\end{abstract}

Keywords: Students' residential environment, Physical characteristics, University students, Cooking and eating 


\section{INTRODUCTION}

Students' residential environments are integral parts of campuses that are expected to enhance the wellbeing of students as they live independently and take responsibility for all areas of life throughout their period of stay in the tertiary institution. University residential environments expose students to various lifestyle behaviours that can have immediate or long term health implications. Part of these lifestyle behaviours include nutritional intake (Brunt \& Rhee, 2008). Students take responsibility for feeding and make food choices daily as they engage in many food-related activities on campus. Food is a basic necessity of life especially among young adults (Rahji \& Rahji, 2014). Dietary habits may mean any task or action which has to do with food. These may include food acquisition, food preparation, food consumption and diet management. Preference for processed foods observed among students as a result of increased exposure to advertisements and easy access to supermarket, has become an issue of global concern (Akinleye \& Rahji, 2006). This is because regular consumption of fast or processed foods is known to be associated with incessant rate of obesity and other diet-related illnesses particularly in developing countries (Duffey et al, 2009). This trend in fast food consumption is associated with increase in calories and poor diet quality because they lack basic nutrients needed for growth and cognitive development (Mancino, Todd \& Lin, 2009). Other negative dietary habits common among university students include meal skipping and low fruit and vegetable consumption (Abdull-Hakim, Muniandy \& Danish, 2012). These habits are influenced by poor food access and availability in the local environment (Chen \& Yang, 2014).

The case of university students in developing countries like Nigeria is not different as the problem of poor dietary intake has been attributed to poverty (Otemuyiwa \& Adewusi, 2013; Ahmadu \& Edeoghon, 2018). Public universities in Nigeria used to operate the cafeteria system where the government took sole responsibility for the accommodation of all students on campus and the provision of quality dining facilities and services at subsidized rates. Since 1984, universities have witnessed massive increase in student population yearly without commensurate increase in the provision of housing facilities. This has led to the cessation of the cafeteria system, with students taking major responsibility for housing and feeding at increasing costs (National Universities Commission, 2003; Otemuyiwa \& Adewusi, 2013). Students housing in Nigerian universities mainly comprise the on-campus and off-campus residential settings. Najib et al (2012) explained that on-campus housing is majorly situated on the campus environment, with the institution as the owner and manager while off-campus housing on the other hand is built and managed by private investors outside the campus premises. Student on-campus housing, which makes up the residential environment, bears much significance for institutions because it constitutes the largest facility asset of any 
institution (Amole, 2009). As such, the design of student residential environment need to be specially considered because it creates the platform within which students make food choices and carry out domestic and social activities from day to day.

The University of llorin, a fast growing public university in North Central Nigeria has a unique residential environment setting as a result of the involvement of private developers in the provision of on-campus accommodation unlike other public universities where private developers only provide off-campus accommodation for students. This has led to an increase in the population of students accommodated on campus in recent time. The food behaviour of these students is important in maintaining good health and wellbeing all through their stay on campus and this is dependent on what is easily accessible by them in their residential environment (Chen \& Yang, 2014).

Few studies have examined students' residential environments as they relate to dietary habits. For instance, Jaworowska and Bazylak (2007) estimated the nutrient intake as well as nutritional status of female pharmacy students in Bydgoszcz, and the relationship of these factors with the type of residence during an academic year. The result of the study revealed that the dietary intake of students residing with parents was poorer than students living away from family home. Brunt and Rhee, (2008); El Ansari, Stock, and Mikolajczyk, (2012); Laska, Larson, Neumark-sztainer, and Story, (2009), in their cross-sectional studies revealed the effects of on-campus, off-campus, and family home residential environment on students' food choices and consumption. The result of their studies revealed that nutrition habits of students differed according to their residential environment. Family, home and on-campus residents displayed healthier nutrition habits than those off-campus. On the contrary, Gonzales (2013) in his study on the impact of residence on dietary intake, food insecurity, and eating behavior among university undergraduate students revealed that residence type (on-campus, offcampus, and family home) did not have any impact on the dietary behaviour of students. Furthermore, issues related to living arrangements and eating behaviour among students seem exaggerated according to Mann and Blotnicky (2017) as healthy eating is only slightly influenced by type of residence (with parents, in apartments, or on-campus).

The residential environment in which students live have been observed to influence dietary habit in a measure. Students, especially those who live independently i.e. away from parent and family home have been reported to practice negative dietary habits which can have health implications especially as they grow older (Macino, Todd \& Lin, 2009; Abdull-Hakim, Muniandy \& Danish, 2012; Otemuyiwa \& Adewusi, 2013). Several factors including a higher perception of stress, low self-esteem, lack of discipline and time, self-control, social support, product prices (costs), limited budgets, availability of and access to (healthy) food options and type of residence (i.e. with parents or away from family) were reported as important 
influencing factors of students' dietary behaviours (Cartwright et al, 2003; Huntsinger \& Luecken, 2004; Cluskey \& Grobe, 2009; Greaney et al, 2009; Nelson, Kocos, Lytle, \& Perry, 2009). However, it remains unknown whether the physical characteristics of students' residential environment affect their dietary habits. Knowledge of the influence of the physical attributes of students' residential environment in relation to dietary habits may be important in influencing students housing policy and making recommendations that can improve students' dietary behaviour. This cross-sectional study is therefore aimed at describing the physical characteristics of students' residential environment that are important for cooking and eating in University of Ilorin, Nigeria so that recommendations can be made to enhance student housing policy. The specific objectives were to: describe the socio-economic characteristics of students on campus residence halls (ii) determine the design of residence halls on campus with respect to kitchen arrangement and identify the additional facilities available that could aid students' eating habits, and to: (iii) examine the type and number of food outlets available within the students' residential environment.

\section{METHODOLOGY}

\section{The Study Area}

University of llorin is situated in the ancient city of llorin on latitude $8^{\circ} 30^{\prime} \mathrm{N}$ and longitude $4^{\circ}$ $32 ' \mathrm{E}$. llorin, the capital of Kwara State, is geographically positioned in the "middle belt" region of Nigeria where there is a cultural confluence of the North and South.

The University of Illorin was established in 1975 as a University College affiliated to the University of Ibadan. The University took off as a mini campus on its temporary site at the Kwara State Polytechnic with three faculties, namely: Faculties of Arts, Science and Education. The faculties later evolved into six and incorporated Faculties of Engineering \& Technology, Business and Social Sciences, and Basic Clinical Sciences.

In January 1982, the University moved to its permanent site after the completion of new Faculty blocks and residences for Natural Sciences and Engineering with a record of more than 1000 students studying in sciences. The permanent site of the institution has a land mass of about 15,000 hectares and this makes it the largest university in Nigeria in terms of land mass. The University now has fifteen Faculties and over sixty Academic Departments. Since 2002 to date, there has been an upsurge in the physical development of the main campus which is on the permanent site in terms of academic, administrative and students' residential facilities. At the time of this research, there are a total of twenty (20) residence halls on campus which consist of six (6) public hostels and fourteen (14) private residence halls. The public residence halls are owned and managed by the institution while the private residence halls are owned and managed by private individuals in partnership with the 
university. They public and private residence halls are situated on the university campus. The staff and student populations are now about 3,500 and 40,000 respectively. However, due to the shortage of hostel facilities, the university has only been able to accommodate about $15 \%$ of the student population on campus leaving the other $75 \%$ to seek for accommodation off campus (University of Ilorin, n.d).

\section{Sampling Procedure and Sample Size}

The research design employed was a descriptive survey. Questionnaire and structured observation schedule were used as the instrument for data collection. The study focused on the on-campus residential environment of undergraduate students in the University of Ilorin. This includes the residence halls, their environs, and the facilities within the residence hall environment. The study population comprised all the students residing on the campus residence halls in the University of llorin. This included both private and public residence halls on the University campus. A multi-stage sampling technique was adopted to select samples. In the first stage, twelve (12) residence halls were purposively selected out of the twenty (20) residence halls on campus based on three criteria, namely: ownership (institution owned or owned by private individuals), gender (male or female), and design type (with or without kitchen facility, restaurant, buttery, balcony and backyard) as shown in figure 1. The second stage was the systematic selection of $12 \%$ of students in each of the twelve (12) residence halls. The first student in each of the residence halls was selected randomly. Four hundred and thirty (430) copies of questionnaire were administered on the students and 416 were retrieved representing a response rate of $97 \%$. Information obtained through the use of questionnaire included the socioeconomic/demographic characteristics of students and the perceived distance of students' residence halls to restaurants in the residential environment. The schedule was prepared and filled objectively by the researcher. The data collected included the residence hall design, availability of kitchen, washing sinks, and worktops, storage and availability of shopping and restaurant facilities in the residence halls. 
Fig. 1: Analysis of the sampling technique used for the study

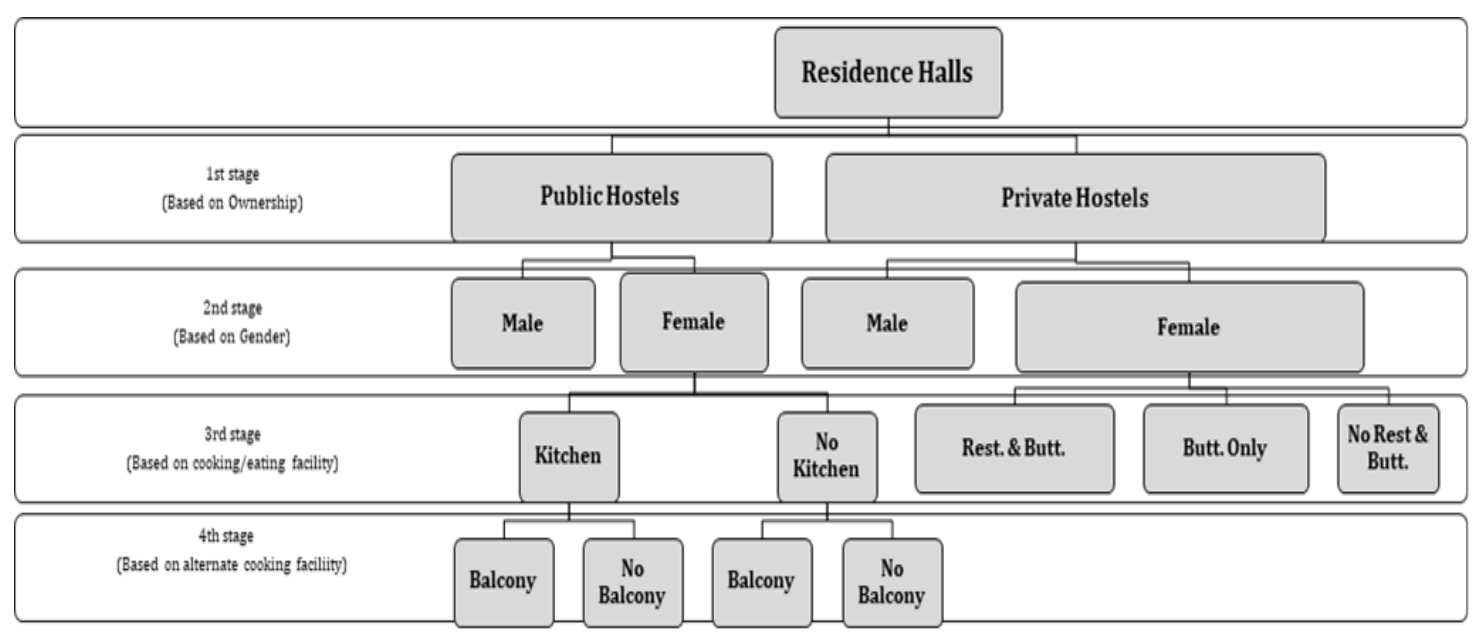

The 12 residence halls purposively selected out of all the 20 residence halls consisted of:

- 5 public and 7 private residence halls;

- 2 male and 10 female residence halls;

- 3 with kitchen facility, 2 without kitchen facility, 3 with Restaurant \& Buttery, 3 with Buttery only and 1 without Restaurant \& Buttery;

- 2 with balconies, 1 without balcony, 1 with backyard, 1 without backyard, 7 without balconies nor backyard.

\section{Data Analysis}

Statistical analysis was performed using the Statistical Package for Social Scientists (SPSS) software version 16 . Analytical tools used for the study were mainly descriptive statistics such as frequency tables and percentages.

\section{RESULTS AND DISCUSSION}

\section{Socio-economic Characteristics of Students}

The results of the socioeconomic characteristics of the students in Table 1 showed that majority $(72.4 \%)$ were females while only a few $(27.6 \%)$ were males. This indicates that more females resided on campus than males. The results also revealed that $17.5 \%$ of the students were less than 18 years of age, $54.3 \%$ were between the ages of 18 and 20 years, $24.8 \%$ were between the ages of $21-24$ years; while $22.2 \%$ were more than 24 years of age. This indicates that most of the students (79\%) were between the ages of 18 and 24 years and were fairly distributed among 100 to 300 levels. In addition, most (62.5\%) of the students had lived in their residence halls for a period of at least one session. This implies that they would 
be familiar enough with the residential environment to enable them supply sufficient information about it.

Table 1: Distribution of students based on socio-economic characteristics ( $\mathrm{N}=416$ )

\begin{tabular}{lll}
\hline Variables & Frequency & Percentage $(\%)$
\end{tabular}

Gender:

Male

115

27.6

Female

301

72.4

Age (in years):

$<18$

73

17.5

$18-20$

226

54.3

$21-24$

103

24.8

$>25$

9

2.2

Level:

100

200

116

27.9

300

106

25.5

400

72

17.3

$>400$

10

2.4

Length of stay (in the residence hall):

$<$ One semester

12

2.9

One semester

22

5.3

$<$ One session

120

28.8

One session

260

62.5

Source: Field Survey, 2018 


\section{Residence Hall Design}

Table 2 shows the design of the residence halls with respect to room-kitchen design and arrangements. The table shows that $67 \%$ of the residence halls selected were the suite type (a room with kitchen en suite); $8 \%$ shared kitchen (two rooms sharing a kitchen space); $8 \%$ had kitchen per floor design (a number of rooms sharing a kitchen space per floor or level) while $17 \%$ had no kitchen space provided in the residence hall. The results also showed that $83 \%$ of the residence halls surveyed had kitchens within them while $17 \%$ had no kitchens. It is worthy of note that the commonest residence hall design among the halls selected was the suite type. The suite type design is however common with the private residence halls while the kitchen per floor design is common with the public residence halls. The result suggests that most of the students would find it easy to access the cooking area since the kitchens are located in the rooms. It also suggests that the culinary habits of the students would be enhanced since most of the residence halls had kitchens within them.

Table 2: Distribution of residence halls by design

\begin{tabular}{lll}
\hline Variables & Frequency & Percentage (\%) \\
\hline Residence hall design: & & \\
Suite type & 8 hostels & 67 \\
Shared kitchen & 1 hostel & 8 \\
Kitchen per floor & 1 hostel & 8 \\
No kitchen & 2 hostels & 17 \\
\hline
\end{tabular}

Source: Field Survey, 2018

\section{Additional Facilities in the Residence Hall}

Table 3 shows the additional facilities for shopping and eating within the residence halls. It shows that $42 \%$ of the residence halls had restaurants and butteries within them, $50 \%$ had butteries only while $8 \%$ had no restaurant and no buttery. The result reveals that most of the residence halls had restaurants and buttery spaces in them to aid the eating and shopping activities of students. This result suggests that most of the students would find eating and shopping activities easy within the residence halls because of close proximity. 
Table 3: Distribution of additional facilities in the students' residence halls

\begin{tabular}{lll}
\hline Variables & Frequency & Percentage (\%) \\
\hline Additional facility: & & \\
Restaurant and buttery & 5 hostels & 42 \\
Restaurant only & 0 & 0 \\
Buttery only & 6 hostels & 50 \\
No restaurant and no buttery & 1 hostels & 8
\end{tabular}

Source: Field Survey, 2018

\section{Type and Number of Food Outlets within the Residential Environment on Campus}

The results on the various types, number and locations of food outlets within the University campus are presented in Table 4. Findings reveal that $35 \%$ of the food outlets were snacks shops; $38 \%$ were butteries; $19 \%$ were restaurants; $6 \%$ were ready-to-eat food vendors; $1 \%$ mainly sell vegetables and raw foods while $2 \%$ sell frozen foods, vegetables and raw foods. The results depict that $73 \%$ of all available food outlets were snack shops and butteries. This may suggest a high consumption of snacks and junk foods among students because of the availability of many snacks shops and butteries on campus.

Table 4: Distribution of type of food outlets in the students' residence halls

\begin{tabular}{llll}
\hline S/N & Types & Frequency & Percentage \\
\hline $\mathbf{1}$ & Snack shops (Snacks \& drinks) & 62 & $35 \%$ \\
$\mathbf{2}$ & Butteries (Provisions, snacks \& drinks) & 68 & $38 \%$ \\
$\mathbf{3}$ & Restaurants & 32 & $18 \%$ \\
$\mathbf{4}$ & Ready-to-eat food vendors & 10 & $6 \%$ \\
$\mathbf{5}$ & Frozen foods only & 0 & 0 \\
$\mathbf{6}$ & Vegetables (tomatoes, pepper \& vegetables) only & 0 & 0 \\
$\mathbf{7}$ & Raw foods store (raw rice, beans, yams, etc.) only & 0 & 0 \\
$\mathbf{8}$ & Vegetables and raw foods & 2 & $1 \%$ \\
$\mathbf{9}$ & Frozen foods, vegetables and raw foods & 4 & $2 \%$ \\
\hline
\end{tabular}

Source: Field Survey, 2018

\section{Perceived Distance of Residence Halls to Restaurants}

Table 5 shows the subjective distances from the residence halls to the restaurants. The table reveals that $17.1 \%$ of the students reported that the restaurants were very close to their residence halls; $46.9 \%$ reported that they were close; $24.3 \%$ reported that they were far; $4.6 \%$ reported that they were very far; while $7.2 \%$ reported that the information was not 
applicable to them because they do not patronize restaurants. It can be deduced that for most of the students, the restaurants often patronized were close to their residence halls. The result suggests frequent restaurant patronage among students due to close proximity.

Table 5: Perceived distance of residence hall to restaurants

\begin{tabular}{lll}
\hline Distance of residence hall to restaurant & Frequency & Percentage (\%) \\
\hline Very close & 71 & 17.1 \\
Close & 195 & 46.9 \\
Far & 101 & 24.3 \\
Very far & 19 & 4.6 \\
Not applicable & 30 & 7.2
\end{tabular}

Source: Field Survey, 2018

\section{CONCLUSION AND RECOMMENDATIONS}

The study revealed the physical attributes of students' residential environment in relation to dietary habits in University of llorin, Nigeria. The suite type (kitchen en suite) residence hall was the commonest residence hall design observed on campus. Also, most of the residence halls had restaurants and buttery spaces in them to aid the cooking and eating habits of students. Furthermore, the study revealed that majority of the food outlets available on campus were snack shops and butteries, which may suggest a high consumption of snacks and junk foods among students.

Based on these findings, the following recommendations were made:

1. More restaurants should be provided on campus to enable students to access healthier food options than the snacks and sugary drinks that are mainly available at the snack shop and butteries which were found to be dominant.

2. The built environment professionals, developers, stakeholders and polices on student housing should pay more attention to the provision of facilities such as kitchens and restaurants within students' residential environment so that the cooking and eating habits of students would be enhanced. These facilities should be provided in the residence halls from the building design stage.

3. The kitchen facilities should be provided within the students' rooms or at close proximity to the students' room for easy accessibility and to encourage use. 


\section{REFERENCES}

Abdull-Hakim, N. H., Muniandy, N. D., and Ajau, D. (2012). "Nutritional status and eating practices among university students in selected universities in Selangor, Malaysia". Asian Journal of Clinical Nutrition, 4(3): 77-87. DOI: 10.3923/ajcn.2012.77.87

Ahmadu, J. and Edeoghon, C.O. (2018). "Effect of maize production on poverty alleviation of farmers in Edo State, Nigeria". Agrosearch, 18(1): 53-65.

Akinleye, S.O. and Rahji, M.A. (2006). "Nutritional implications of the demand for foods in Nigeria". Agrosearch, 8 (1): 35-45.

Amole, D. (2009). "Residential satisfaction in students housing". Journal of Environmental Psychology, 29: 76-85.

Brunt, A. R., and Rhee, Y. S. (2008). "Obesity and lifestyle in US college students related to living arrangements". Appetite, 51(3): 615-621.

Cartwright, M., Wardle, J., Steggles, N., Simon, A. E., Croker, H., and Jarvis, M. J. (2003). "Stress and dietary practices in adolescents". Health Psychology, 22 (4): 362-369.

Chen, X., and Yang, X. (2014). "Does food environment influence food choices? A geographical analysis through "tweets". Applied Geography, 51: 82-89.

Cluskey, M., and Grobe, D. (2009). "College weight gain and behavior transitions: male and female differences". Journal of American Diet Association, 109 (2): 325-329.

Duffey, K. J., Gordon-Larsen, P., Steffen, L. M., Jacobs, D. R., and Popkin, B. M. (2009). "Regular consumption from fast food establishments relative to other restaurants is differentially associated with metabolic outcomes in young adults". The Journal of Nutrition. 139(11): 2113-2118.

El Ansari, W., Stock, C., and Mikolajczyk, R. T. (2012). "Relationships between food consumption and living arrangements among university students in four European countries-a cross-sectional study". Nutrition Journal, 11(28).

Gonzales, K. (2013). "The impact of residence on dietary intake, food insecurity, and eating behavior among university undergraduate students". Ursidae: The Undergraduate Research Journal at the University of Northern Colorado, 3(2): 113-130. 
Greaney, M. L., Less, F. D., White, A. A., Dayton, S. F., Riebe, D., Blissmer, B., ...Walsh JR, G. G. (2009). "College Students' barriers and enablers for healthful weight management: a qualitative study". Journal of Nutrition, Education and Behaviour, 41(4): 281-286.

Huntsinger, E. T., and Luecken, L. J. (2004). "Attachment relationships and health behavior: The mediational role of self-esteem". Psychology and Health, 19: 515-526.

Jaworowska, A., and Bazylak, G. (2007). "Residental factors affecting nutrient intake and nutritional status of female pharmacy students in Bydgoszcz". Advances in Medical Sciences, 52 (1): 245-251.

Laska, M. N., Larson, N. I., Neumark-sztainer, D., and Story, M. (2009). "Dietary patterns and home food availability during emerging adulthood: do they differ by living situation?". Public Health Nutrition, 13(2): 222-228.

Mancino, L., Todd, J., and Lin, B. (2009). "Separating what we eat from where: Measuring the effect of food away from home on diet quality". Food Policy, 34(6): 557-562.

Mann, L., and Blotnicky, K. (2017). "Influences of physical environments on university student eating behaviours". International Journal of Health Sciences, 5(2): 42-52.

Najib, N.U., Yusof, N., and Sani, N.M. (2012). "The effects of students' socio-physical backgrounds onto satisfaction with student housing facilities". Procedia-Social and Behavioral Sciences. 62: 64-74.

National University Commission, (2003). Monogragh series Abuja, (1) 4.

Nelson, M. C., Kocos, R., Lytle, L. A., and Perry, C. L. (2009). "Understanding the perceived determinants of weight-related behaviors in late adolescence: a qualitative analysis among college youth". Journal of Nutrition, Education and Behavaviour, 41(4): 287292.

Otemuyiwa, I. O., and Adewusi, S. R. (2012). "Food choice and meal consumption pattern among undergraduate students in two universities in Southwestern Nigeria". Nutrition and Health, 21(4): 233-245.

Rahji, F.R. and Rahji, M.A.Y. (2014). "A comparative analysis of diet quality in urban and rural households in Ibadan zone of Oyo State, Nigeria". Agrosearch, 14(2): 90-102.

University of Ilorin (n.d.). About us. Retrieved February 05, 2019 from http://www.unilorin.edu.ng/index.php/about-us. 